\title{
PREFÁCIO
}

Recebi a elevada e honrosa missão de prefaciar o dossiê acadêmico composto de importantes artigos escritos por Joelma Boaventura da Silva, Stimison Flammarion Oliveira Tarrão, Stephanie Carvalho Magalhães, Jaciel Boaventura da Silva, Luan Victor de Souza Bispo, Geórgia Rocha Roma, Miriam Kelly Teixeira Silva e Gine Alberta Ramos Andrade Kinjyo, todos eles nas áreas do Direito e do Processo do Trabalho.

Profundos, claros, objetivos e essenciais... Os textos que ingressam na Revista Renove e que estão sob os seus olhos, é um produto intelectual de um dedicado grupo empenhado em analisar as reflexões interdisciplinares no âmbito jurídico trabalhista. Eles representam, sem dúvidas, alguns dos mais expressivos nomes da nova safra de doutrinadores do Direito e do Processo do Trabalho, sempre comprometidos em oferecer o que há de melhor em cada pesquisa.

Os elogios ora apresentados adquirem maior relevo quando percebemos que os autores conseguiram expor de forma sistematizada e cuidadosa os conteúdos de questões delicadas e de imensa importância prática. Eles realmente demonstraram uma multiplicidade de sólidos conhecimentos nos âmbitos constitucional e infraconstitucional, sem, entretanto, perderem a objetividade e a leveza essenciais aos escritos de consulta.

Entre os vários méritos dos textos aqui encontrados, um dos que mais se destaca é, sem dúvidas, o de saber conciliar aprofundamento temático com clareza na transmissão das ideias, qualidades que sempre precisam ser ressaltadas, notadamente quando se consegue decifrar linguagens específicas e simplificar compreensões.

Cabe salientar, ainda, que os textos reuniram, com notável atualidade, os pilares do aprendizado de qualquer disciplina jurídica, expondo de forma sistematizada tanto as disposições normativas, quanto os entendimentos doutrinários e os posicionamentos jurisprudenciais aplicáveis a cada uma das muitas situações por eles tratadas.

Com elegante fraseado, os autores visitaram as mais significativas doutrinas produzidas sobre as diversas matérias estudadas, mas não se contentaram em oferecer unicamente alicerces conceituais. Ao extrapolar os lindes da reprodução dos pensamentos sobre os institutos visitados, construíram conclusões e sistematizações originais sempre bem 
fundamentadas, oferecendo novas perspectivas até mesmo sobre entendimentos aparentemente solidificados pela ação do tempo.

Os autores - saliente-se - identificaram nuances e novas perspectivas nas edificações legislativas, mas, nesse processo, revelaram a importante habilidade de saber respeitar as tradições normativas clássicas.

Esses novos e promissores nomes das letras jurídico-trabalhistas, enfim, conseguiram ser, a um mesmo tempo, informativos e críticos, atribuindo aos seus leitores desde as reflexões iniciais que produziram a norma até as discussões quanto à sua aplicação ou inaplicação em determinadas passagens polêmicas a partir do filtro da conformidade com a Constituição.

Não tenho dúvidas de que vemos aqui germinar uma nova safra de valores na pesquisa e na docência jurídica. Cabe-nos celebrar o acontecimento e prestigiar tão boas reflexões.

\section{Luciano Martinez.}

Mestre e Doutor em Direito do Trabalho e da Seguridade Social pela USP Pós-Doutor pela PUCRS.

Professor Associado I da Universidade Federal da Bahia.

Juiz do Trabalho.

Da Academia Brasileira de Direito do Trabalho 